\title{
Meta-Analysis of the Effect of Variety of Learning Models on Students' Mathematic Creative Thinking Ability
}

\author{
Rizka Nurlina Damanik, Bornok Sinaga, E. Elvis Napitupulu \\ Mathematics Education Study Program, Medan State University, Indonesia
}

\begin{abstract}
This study aims: (1) to analyze the effect size of the learning model on students' mathematical creative thinking abilities; (2) to find out the right learning model to improve students' mathematical creative thinking skills; (3) to do a meta-analysis of the influence of the learning model on the mathematical creative thinking ability of junior high school students. The data used as a meta-analysis of the selected articles are statistical data to be able to calculate the effect size and standard error. Furthermore, after passing this stage, a meta-analysis was carried out to determine heterogeneity, summary effect and evaluation of publication. Based on the results of the analysis conducted from 16 studies, it was found that 1 study had the highest effect size with the application of the Project Based Learning Model with an effect size value of 0.875 . This study has the highest magnitude of influence among other studies. Furthermore, the largest effect size ranks second and third with an effect size value of 0.828 and 0.719 . The project-based learning model (PBL) is considered more effective to improve the mathematical creative thinking skills of junior high school students with an effect of 0.875 . The results of the meta-analysis of the learning model on students' mathematical creative thinking skills are classified in the strong category withstrong with $\mathrm{r}_{\mathrm{RE}}=0.455$.
\end{abstract}

Keywords: Meta-analysis, Learning Model, Mathematical Creative Thinking Ability

DOI: $10.7176 / \mathrm{JEP} / 12-32-12$

Publication date: November $30^{\text {th }} 2021$

\section{PRELIMINARY}

Mathematics is a branch of science that has an important role in various aspects. Called to have an important role because the application of mathematics is used in everyday life. This is in line with Anggirena (2014) which states that everyday human life cannot be far from mathematics, be it from small things to complex technological developments. Relevant to this opinion, Daut (2016) says that mathematics as a field of science plays an important role in the development of science and technology, both as a support for the application of other fields of science and the development of mathematics itself.

According to NCTM (2000) the mathematical thinking process in mathematics learning includes five main standard competencies, namely problem solving skills, reasoning abilities, connection skills, communication skills and representation skills. Jazuli (2009:209) concludes that this low ability will result in the low quality of human resources, which is shown in the low ability to think critically and creatively. As happened in the research results, it is still found that students' mathematical creative thinking abilities are low. This is also proven through Fardah's research (2012). The conclusion of this study is the low creative thinking ability of students where the creative thinking ability of students for the high category is 6 students $(20 \%)$, the medium category is 10 students $(33.33 \%)$.

Based on the results of the Trend International Mathematics and Science Study (TIMMS) it is stated that the level of creative thinking ability of students in Indonesia is low because only $2 \%$ of Indonesian students can work on questions in the high and advanced categories that require creative thinking skills in solving them (Ismara, 2017: 1). This statement is in line with Alvionita's (2018) statement which states that low mathematics learning outcomes indicate something is wrong and not optimal in mathematics learning, causing students' low mathematical creative thinking skills.

Meta-analytical research itself is defined as research that uses studies that have been used by previous researchers which are carried out systematically and quantitatively. Meta-analytical research includes research that needs to be done. Besides being able to help research users in choosing the right learning model, metaanalysis research needs to be done because the research that has been done is not always perfect. To answer user questions about research results that are effective to use, researchers must look for the effect size value of each study that has been collected. Effect size itself is defined as a quantitative index used to summarize the results of the study. Based on the problems that have been described, for that researchers need to research, review the problems that arise. Therefore, researchers will conduct a meta-analysis of the influence of the learning model on students' mathematical creative thinking skills.

\section{RESEARCH METHODS}

\subsection{Subject and Object}

The subjects in this study were all research results that were used as data sources in this study, namely a 
collection of articles on the influence of various learning models on students' mathematical creative thinking abilities. Meanwhile, the object of research is the influence of various learning models on students' mathematical creative thinking abilities.

\subsection{Research Instruments}

The instrument used in this study was a coding data sheet. The coding process will first be recorded starting from the title of the article, year of the article, name of the author, type of research, agency, article link address and article accreditation.

\subsection{Data analysis}

According to Becker \& Park (in Ramadhani, et al, 2021:80) data analysis techniques in calculating effect size values can use several formulas such as the following:

Mean and standard deviation of two group posttest only

$$
E S=\frac{\bar{X}_{E-\bar{X}_{C}}}{S D_{C}}
$$

If the standard deviation is not known, the effect size can be calculated using the t-test

$$
E S=\mathrm{t} \sqrt{\frac{1}{n_{E}}+\frac{1}{n_{C}}}
$$

Mean and standard deviation of two groups pretest-posttest

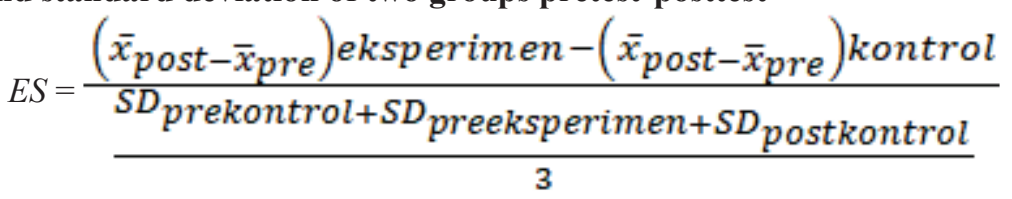

Chi-square

$$
E S=\frac{2 r}{\sqrt{1-r^{2}}} ; \mathrm{r}=\sqrt{\frac{\chi^{2}}{n}}
$$

If a study in a meta-analysis is based on the same type of data (mean, binary, or correlation), the researcher must select an effect size based on that type of data. While some studies use averages, others use binary data, and others use correlational data, then we can apply formulas to convert between effect sizes. Furthermore, Cohen (1988) provides a reference for assessing the magnitude of the effect size value, namely $\mathrm{f}=0.1$ for a small effect size, $\mathrm{f}=0.25$ for medium, and $\mathrm{f}=0.4$ for large. Furthermore, the correlation meta-analysis provides a reference for assessing the magnitude of the value. Retnawati et al, (2018:143) stated that if the value of $r 0.10$ then the correlation is in the "weak" category, if $r=0.25$ then the correlation is in the "medium" category.

\section{RESULTS AND DISCUSSION}

a) Effect Size Conversion Result Data Based on Correlation Data

Table 1. Effect Size Konversi Conversion Results Based on Correlation Data

\begin{tabular}{|c|c|c|c|c|c|}
\hline NO & $\begin{array}{c}\text { ARTICLE } \\
\text { CODE }\end{array}$ & $\begin{array}{c}\text { RESEARCHER'S } \\
\text { NAME }\end{array}$ & LEARNING MODEL USED & $\begin{array}{c}\text { EFFECT } \\
\text { SIZE (R) }\end{array}$ & DESCRIPTION \\
\hline 1 & $1 \mathrm{~A}$ & $\begin{array}{c}\text { Noviyani } \\
\text { Florentina \& } \\
\text { Leonard }\end{array}$ & $\begin{array}{c}\text { Experiment Class : Jigsaw . } \\
\text { Cooperative Learning Model } \\
\text { Control Class: Think Pair Share } \\
\text { (TPS) Cooperative Learning Model }\end{array}$ & 0.283 & Verified \\
\hline 2 & $3 \mathrm{~A}$ & $\begin{array}{c}\text { Yenni \& Silvi Elya } \\
\text { Putri }\end{array}$ & $\begin{array}{c}\text { Experiment Class : Themed } \\
\text { Problem Based Learning } \\
\text { Control Class : Problem Based } \\
\text { Learning }\end{array}$ & 0.340 & Verified \\
\hline 3 & $4 \mathrm{~A}$ & Ahmad Fadillah & $\begin{array}{c}\text { Experiment Class : Problem } \\
\text { Solving Learning Model } \\
\text { Control Class : Conventional } \\
\text { Learning }\end{array}$ & 0.465 & Verified \\
\hline
\end{tabular}




\begin{tabular}{|c|c|c|c|c|c|}
\hline NO & $\begin{array}{l}\text { ARTICLE } \\
\text { CODE }\end{array}$ & $\begin{array}{c}\text { RESEARCHER'S } \\
\text { NAME }\end{array}$ & LEARNING MODEL USED & $\begin{array}{l}\text { EFFECT } \\
\text { SIZE (R) }\end{array}$ & DESCRIPTION \\
\hline 4 & $5 \mathrm{~A}$ & Attin Warmi & $\begin{array}{c}\text { Experiment Class: Problem Based } \\
\text { Learning Model } \\
\text { Control Class : Conventional } \\
\text { Learning }\end{array}$ & 0.719 & Verified \\
\hline 5 & $21 \mathrm{~A}$ & $\begin{array}{l}\text { Zahrina Nurjannah } \\
\text { \& Ade Irma }\end{array}$ & $\begin{array}{c}\text { Experiment Class : Creative } \\
\text { Problem Solving Learning Model } \\
\text { Control Class : Direct Learning } \\
\text { Model }\end{array}$ & 0.319 & Verified \\
\hline 6 & $25 \mathrm{~A}$ & Hesti Noviyana & $\begin{array}{c}\text { Experiment Class : Project Based } \\
\text { Learning Model } \\
\text { Control Class : Conventional } \\
\text { Learning }\end{array}$ & 0.875 & Verified \\
\hline 7 & $27 \mathrm{~A}$ & $\begin{array}{c}\text { Ari Septian \& Riki } \\
\text { Rizkindi }\end{array}$ & $\begin{array}{c}\text { Experiment Class : Project Based } \\
\text { Learning Model } \\
\text { Control Class : Conventional } \\
\text { Learning }\end{array}$ & 0.828 & Verified \\
\hline 8 & $28 \mathrm{~A}$ & Gias Atikasari & $\begin{array}{c}\text { Experiment Class : Cooperative } \\
\text { Learning Model Using Think Talk } \\
\text { Write (TTW) Strategy } \\
\text { Control Class : Expository Learning }\end{array}$ & 0.404 & Verified \\
\hline 9 & $32 \mathrm{~A}$ & $\begin{array}{l}\text { Farida Maria Ulfa } \\
\text { \& Maya Asriana }\end{array}$ & $\begin{array}{l}\text { Experiment Class : Project Based } \\
\text { Learning Model } \\
\text { Control Class : Expository Learning }\end{array}$ & 0.408 & Verified \\
\hline 10 & $39 \mathrm{~A}$ & $\begin{array}{c}\text { Princess Ningsih } \\
\text { Yelni }\end{array}$ & $\begin{array}{c}\text { Experiment Class : Generative } \\
\text { Learning Model } \\
\text { Control Class : Conventional } \\
\text { Learning } \\
\end{array}$ & 0.375 & Verified \\
\hline 11 & $40 \mathrm{~A}$ & $\begin{array}{l}\text { Muhammad } \\
\text { Saman }\end{array}$ & $\begin{array}{c}\text { Experiment Class : Model Guided } \\
\text { Discovery Learning } \\
\text { Control Class : Conventional } \\
\text { Learning } \\
\end{array}$ & 0.351 & Verified \\
\hline 12 & $41 \mathrm{~A}$ & Asti Asterina & $\begin{array}{c}\text { Experiment Class : } \\
\text { Problem Centered Learning Model } \\
\text { Control Class : Conventional } \\
\text { Learning } \\
\end{array}$ & 0.361 & Verified \\
\hline 13 & $42 \mathrm{~A}$ & $\begin{array}{c}\text { Muhammad } \\
\text { Agung Prayogo }\end{array}$ & $\begin{array}{c}\text { Experiment Class: Problem Based } \\
\text { Learning Model } \\
\text { Control Class : Conventional } \\
\text { Learning } \\
\end{array}$ & 0.697 & Verified \\
\hline 14 & $43 \mathrm{~A}$ & Fatima Bilqis & $\begin{array}{c}\text { Experiment Class : Learning Model } \\
\text { Search, Solve Create and Share } \\
\text { (SSCS) } \\
\text { Control Class : Conventional } \\
\text { Learning }\end{array}$ & 0.056 & Verified \\
\hline 15 & $44 \mathrm{~A}$ & $\begin{array}{l}\text { Rizki Fajarini } \\
\text { Hasibuan }\end{array}$ & $\begin{array}{c}\text { Experiment Class : Treffinger's } \\
\text { Learning Model } \\
\text { Control Class : Conventional } \\
\text { Learning } \\
\end{array}$ & 0.526 & Verified \\
\hline 16 & $47 \mathrm{~A}$ & Imas Teti Rohaeti & $\begin{array}{c}\text { Experiment Class : Treffinger's } \\
\text { Learning Model } \\
\text { Control Class : Conventional } \\
\text { Learning }\end{array}$ & 0.289 & Verified \\
\hline
\end{tabular}

b) Categorization of Effect Size Learning Model Results on Improving Mathematical Creative Thinking Ability of Junior High School Students 
Table 2. Data Effect Size Based on Research Independent Variables

\begin{tabular}{|c|c|c|c|}
\hline NO & LEARNING MODEL & $\begin{array}{c}\text { EFFECT } \\
\text { SIZE(R) }\end{array}$ & CATEGORY \\
\hline 1 & Jigsaw Type Cooperative Learning Model & 0.283 & Currently \\
\hline 2 & Learning Model Everyone is a Teacher & 0.340 & Currently \\
\hline 3 & Problem Solving Learning Model & 0.465 & Strong \\
\hline 4 & Problem Based Learning Model & 0.719 & Strong \\
\hline 5 & Creative Problem Solving Learning Model & 0.319 & Strong \\
\hline 6 & Project Based Learning Model & 0.875 & Strong \\
\hline 7 & Project Based Learning Model & 0.828 & Strong \\
\hline 8 & Cooperative Learning Model Using Think Talk Write & 0.404 & Strong \\
\hline 9 & (TTW) Strategy & 0.408 & Currently \\
\hline 10 & Project Based Learning Model & 0.375 & Currently \\
\hline 11 & Model Guided Discovery Learning & 0.351 & Currently \\
\hline 12 & Problem Centered Learning Model & 0.361 & Strong \\
\hline 13 & Problem Based Learning Model & 0.697 & Weak \\
\hline 14 & Learning Model Search, Solve Create and Share (SSCS) & 0.056 & Strong \\
\hline 15 & Treffinger's Learning Model & 0.526 & Currently \\
\hline 16 & Treffinger's Learning Model & 0.289 & . \\
\hline
\end{tabular}

Based on the data contained in Table 2 of the various learning models applied, it appears that the one that has the biggest influence on increasing students' mathematical creative thinking skills is the Project-Based Learning Model with a large effect of 0.875 .

c) Heterogeneity Test

Fixed and Random Effects

\begin{tabular}{lcrc}
\hline & $\mathrm{Q}$ & $\mathrm{df}$ & $\mathrm{p}$ \\
\hline Omnibus test of Model Coefficients & 68.010 & 1 & $<.001$ \\
Test of Residual Heterogeneity & 50.929 & 15 & $<.001$ \\
\hline
\end{tabular}

Note. $p$-values are approximate.

Note. The model was estimated using Restricted ML method.

Based on the data obtained from the JASP software, the results of the analysis showed that the 16 studies analyzed were heterogeneous with large $(\mathrm{Q}=50,929 ; \mathrm{p}<0.001)$. Thus, the model that is more suitable to be used is the random effect size model to be able to estimate the average effect size of a total of 16 studies that have met the requirements to be studied by metaanalysis.

d) Summary effect/ Mean Effect Size

\begin{tabular}{|c|c|c|c|c|c|c|}
\hline & \multirow[b]{2}{*}{ Estimate } & \multirow[b]{2}{*}{ Standard Error } & \multirow[b]{2}{*}{$z$} & \multirow[b]{2}{*}{$p$} & \multicolumn{2}{|c|}{$95 \%$ Confidence Interval } \\
\hline & & & & & Lower & Upper \\
\hline intercept & 0.455 & 0.055 & 8.247 & $<.001$ & 0.347 & 0.564 \\
\hline
\end{tabular}

Based on the results of the analysis using the random effects model, it shows that there is a significant positive correlation between the learning model on students' mathematical creative thinking skills $(\mathrm{z}=8.247$; $\mathrm{p}<0.00195 \%$ CI $[0.347 ; 0.564])$.) and the mean effect size belongs to the strong category. with $\mathrm{rRE}=0.455$. 


\section{e) Forest Plot}

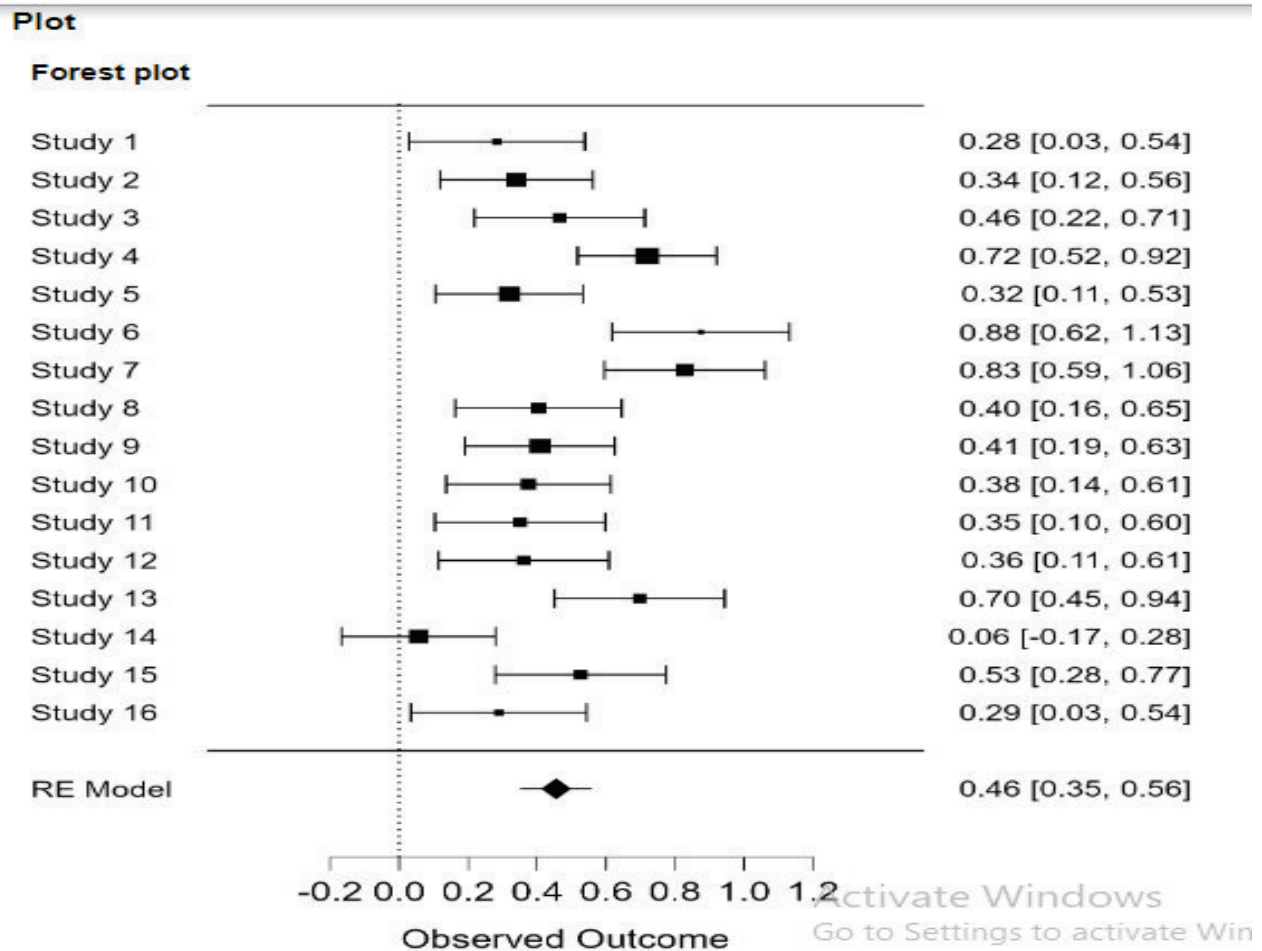

From the forest plot, it can be observed that the effect size in these studies varies from 0.06 to 0.88 .

f) Evaluation of Publication

\section{Funnel Plot}

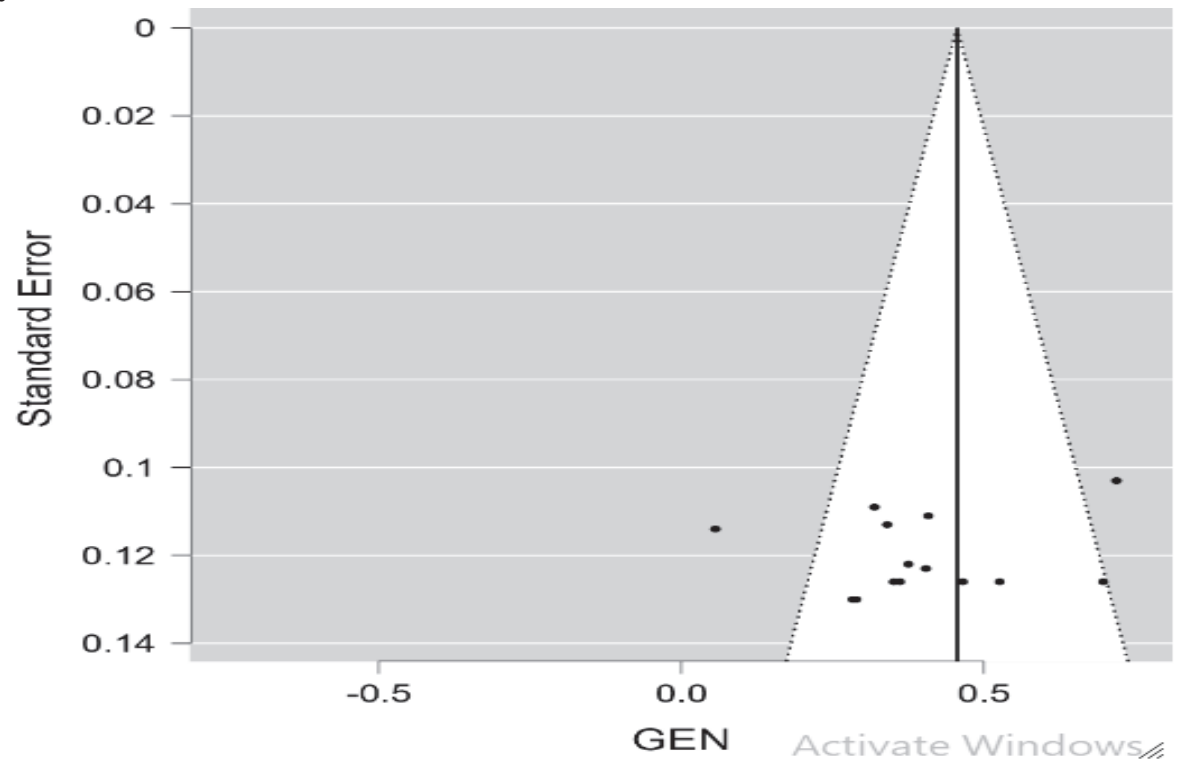

Based on the results of the Fuunel plot above, it is difficult to conclude whether the funnel plot is symmetrical or not due to the irregular distribution of the points, so an egger's test is needed to test whether the funnel plot is symmetrical or not.

\section{Regression test for Funnel plot asymmetry ("Egger's test")}

\begin{tabular}{lll}
\hline & $z$ & $p$ \\
\hline sei & 0.220 & 0.826 \\
\hline
\end{tabular}

Based on the data above, the $p$ value 0.05 . As a rule when accepting the null hypothesis that if if the $p$-value 
0.05 then we must accept the null hypothesis (funnel plot symmetry).

\section{CONCLUSION}

There are sixteen studies that have met the criteria to be used as research material for meta-analysis with a strong mean effect size of 0.455 . One study has the highest effect size with a value of 0.875 among other studies. The research was conducted byHesti Noviyana in 2015 with the implementation of the Project Based Learning Model. Then there is a significant positive correlation between the learning model and students' mathematical creative thinking skills $(\mathrm{z}=8.247$; $<0.00195 \%$ CI $[0.347$; 0.564]). For the $\mathrm{p}$-value 0.05 in the Regression Test for Funnel Plot Asymmetry, there is no publication in the meta-analysis studies that have been carried out.

\section{REFERENCES}

Anggirena, A. (2014). Application of Realistic Mathematics Learning with Whole Brain Teaching on the Subject of the Pythagorean Theorem to Improve Student Learning Outcomes and Activities. UNEJ Educational Journal, 1(2): 40-46.

Becker, K. \& Park, K. 2011. Effects of Integrative Approaches Among Science, Technology, Engineering and Mathematics (STEM) Subjects on Students Learning: a Preliminary Meta-Analysis. Journal of Physics: Conference Series, 1185:012093, 1-9

Cohen, J. (1988). Statistical Power Analysis for The Behavioral Science (2nd ed). Hillsdale NJ: L. Erlbaum Associates.

Daut, S. (2016). Mathematical Connection Ability in Mathematics Learning. MES Journal, 2(1):58-67.

Fardah, D. (2012). Analysis of Students' Creative Thinking Process and Ability in Mathematics Through OpenEnded Tasks. Kreano, 3(2): 1-9

Ismara, L. (2017). Students' Mathematical Creative Thinking Ability in Solving Open Ended Problems in Junior High School. Equatorial Education and Learning, 6(9): 1-8.

Jazuli, A. (2009). Creative Thinking in Mathematical Communication Skills. Paper presented at the National Seminar on Mathematics and Mathematics Education, Mathematics Education FMIPA UNY, Yogyakarta, 5 December.

National Council of Teachers of Mathematics. (2000). Curiculum and Evaluation Standards for School Mathematics. Reston, VA: National Council of Teachers of Mathematics

Ramadhani, et al. (2021). Effect Size Analysis of the Effect of LKS Application on Student Learning Outcomes in Science and Physics Learning. Journal of Science and Science Learning, 5(1): 77-89.

Retnawati, H. et al. (2018). Introduction to Mera Analysis. Yogyakarta: Parama Publishing. 